Article

\title{
The Impacts of Different Sorts of Art Education on Pupils' Preference for 20th-Century Art Movements
}

\author{
Goran Kardum $\mathbb{D}^{\mathrm{D}}$, Dubravka Kuščević and Marija Brajčić *D \\ Faculty of Humanities and Social Sciences University of Split, Poljička cesta 35, 21000 Split, Croatia; \\ gkardum@ffst.hr (G.K.); kuscevic@ffst.hr (D.K.) \\ * Correspondence: mbrajcic@ffst.hr
}

Received: 29 November 2019; Accepted: 23 December 2019; Published: 3 January 2020

\begin{abstract}
The research presented here aims to determine how art education influences students' preferences for the 20th-century art movements. An educational experiment that spanned through one school year was conducted on 200 primary school students. It included three types of intervention: observing works of art from the 20th century, introducing works of art using a puppet, and the students' art activities/artwork based on the 20th-century art movements. The results show that the model of art education is an important factor in changing students' preferences for the 20th century art movements. Students reacted positively to each kind of education, as evidenced in the wider acceptance of 20th-century art (abstract, fauvism, cubism, pop art, and surrealism). The type of education did not influence preferences (as much) when it came to classical art and visual works without artistic value. We concluded that puppets and independent creative work should be used more often in art education.
\end{abstract}

Keywords: art education; 20th century art movements; preferences of arts; pupils

\section{Introduction}

In the times in which we live, visual information far outweighs the verbal kind, and the understanding of visual education is a goal reached through education. The world of imagery is broad, mainly because of the dominance of visual media and technology in the modern world; it is rich with visual signals and symbols present in new forms of communication. In the new forms of visual communication, visual works of art have become a part of the universal visual space of modern culture. Knowing, understanding, and using the language of visual arts is a key component of visual literacy, and an important factor in understanding the world and culture in the 21st century. Education through art is a subject many authors [1-6] have written about. It enables children and the youth to develop ideas, know their feelings and attitudes, and gain experience through different art activities that provide for aesthetic experiences.

Students acquire the language of art through the richness of creative visual content. This is why it is important to enable contact with visual works of art from a young age, as well as to train children to understand that experiencing a work of art is not just about the emotional process, but also about gaining perceptive focus and critical judgement. It is now known that understanding and perceiving art in general—and especially modern art—requires so-called specialized perception, or trained viewing, which is a result of the knowledge and abilities acquired and developed in the process of art education inside and outside of school.

Art education, or an educated taste, is considered less of a fact-based knowledge and more of an ability to define the formal semantic characteristics of a work of art, which is a result of integrating knowledge and other perceptive and cognitive abilities [7]. Knowing the language of art and the experience of observation can be achieved only by continually observing works of art and experiencing 
them. Husković [8] claimed that clarity is a basic assumption and the beginning of an aesthetic act, which presumes the necessity of direct or indirect contact between children and works of art. Many authors [9-11] have put an emphasis on the importance of direct contact between children and works of art, which successfully realizes contextual learning and enables the introduction of the object of knowledge. This also ensures that cultural, contextual, and personal characteristics are respected. Whether observing a reproduction or a piece of original art, it is important that students actively communicate with the offered content. Lachapelle et al. [12] stated that communicating with art should come from a combination of experience- and theory-based learning. Experience-based learning makes the observer interact with a work of art, while theory-based learning requires a cognitive participation, gathering information and filling holes in the knowledge that they have about the work of art in question. The authors above claimed that the interaction and combination of these types of learning is the foundation on which students develop new and complex ways of understanding a work of art.

When a work of art is introduced, every single person is able to decide whether they like it or not. Relations between an individual human being and a work of art are personal and specific. This is why preferences are an interesting starting point in research. Salkind and Salkind [13] believed that preference is a degree of liking or not liking a work of art, while other authors defined preference as a personal phenomenon, which is not tied to an individuals' development phase. They believe it is a result of previous experience, learning experience, socializing, cultural values, and maturity [13]. Chamorro-Premuzic et al. [14] cited a study that emphasized the connection between preference and intelligence, sex, age, level of education, extroversion, etc. Preference for works of art is connected with personality traits, and research shows that the most represented one is openness to new experiences, as a predictor of $33 \%$ of variability [15].

Some research found that the activities of individuals affect their preference. Salkind and Salkind [13] considered preferences to be dependent on the ability to participate in high-quality art activities, such as visiting museums, workshops, gaining experience through travel, etc. Archbell and Stange [16] concluded that aesthetic exposure, education, and experience with works of art influences preferences-in this case, towards art with recognizable or unrecognizable motives. Wiersema [17] highlighted the importance of this in evaluating preferences, as well as the importance of an individuals' personality. Different activities influence an aptitude to art, such as visiting modern museums or archaeological sites, watching science fiction movies or romantic comedies, reading thrillers or poetry, watching classical ballet or modern dance [17].

The art of the 20th century was created as a result of obtaining freedom from an objective necessity of collective understanding of art as a realistic image of an object, which made it manifest itself in many interdependent art movements. The art of the 20th century does not articulate its experience in clear, realistic notions, but by changing conceptions of reality that demand new ways of coding perception schemes that require the observer to put in an effort in understanding. This fact often caused 20th-century art to be perceived badly by an average, artistically non-educated observer.

We have conducted this research to explore whether art education can improve reference, understanding, and observation of 20th-century art. Exploring preferences includes questioning many factors that may influence them in adults, adolescents, and children. These factors include age, sex, sociocultural factors, personality, surroundings, and education. Since the 1930s, scientific research of children's preferences has emerged to clarify the criteria by which children choose works of art [18-27]. All of these indicate that the important factors in children's preferences are motif, color, and realism in depicting a subject. Later research [28-30] showed that younger children prefer realistic art to other kinds. It also showed that, as they age, children become more sensitive to individual styles of art, as well as artistic principles of shaping $[20,21,31-33]$. Some authors $[34,35]$ studied the preferences of visual motifs in pupils.

Kraguljac and Karlavaris [24] studied the connection between preferences and education in grade school, trying to determine whether the value of an experimental program of art appreciation can improve the quality of art education in grade schools. The research took two years and led the 
authors to the conclusion that the experimental program positively influenced the development of appreciative abilities in students. It also showed a positive influence on artistic expression and creative abilities, especially in puberty. Similar results, also indicating a connection between education and a higher aesthetic consciousness, were observed by Cole [36], who studied the influence of aesthetic education adapted to museums on preferences of children aged four, six, and eight. Cole found that a programmatic museum education elevated aesthetic awareness in children. Aylward et al. [37] also researched the influence of artistic education on children. They, too, concluded that artistic education influenced preschool children positively.

Savva and Trimis [38] researched the reactions of preschool children to contemporary art. Their research has shown that a child's contact with works of art (including contemporary art displays in museums) is an important part of their learning experience, if adequate methods are used.

Acer and Omerolu [39] explored the influence of aesthetic education on the evaluation process in six-year-old children. In this case, the education (although of high quality) did not prove to be completely effective in children's aesthetic judgment.

This research aims to show whether art education may be a factor in influencing the preferences regarding 20th-century art in younger grade-school students.

\section{Materials and Methods}

The participants were informed that the research on art preferences was to be conducted at the beginning and the end of a school year.

Data on art preferences were collected while the students observed 36 visual art reproductions on computer screens, coupled so that every pair of reproductions showed a classical work of art and a 20th-century work of art. It was explained to the students that they would be observing images of different periods (without mentioning names of paintings, painters, or art movements), deciding which ones they prefer and immediately rating every image on a scale of 1 to 5 by choosing a smiley face that shows how much they like or dislike a certain image. Imagery of no artistic value was also shown among the reproductions. Fourth-grade pupils used the Likert five-point scale (5-I like it a lot, 4-I like it, 3-neutral, 2-I do not like it, 1-I do not like it at all). First-grade pupils expressed themselves through a visual scale contained of smiley faces.

The pupils evaluated the works of art twice, at the beginning and at the end of a school year. The images were shown in pairs of five rotating matrices, so that the position of the image within a pair would not influence their judgement.

The pairs contained reproductions belonging to art movements up to 1900 and 20th-century art, both mixed with images without artistic value. The evaluation time was $20 \mathrm{~s}$, and the pupils were asked to evaluate as quickly as possible and choose their answer as soon as they saw the images.

The control group in the first $(N=25)$ and third $(N=25)$ grades had no additional education between evaluating works of art at the beginning and the ending of the school year. The experimental groups were working with us during the school year in question. The art education was implemented as follows.

To achieve this goal and these tasks, we conducted empirical research in grade schools with lower-grade pupils, with which we implemented different sorts of art education while observing changes in their preferences before and after education.

The sample comprised 200 primary school students ( 87 boys, 113 girls) who attended first $(N=100)$ and third $(N=100)$ grade. The first-grade students $(N=100)$ were divided into four groups; the control group $(N=25)$ and the experimental groups $\mathrm{A}(N=25), \mathrm{B}(N=25)$, and $\mathrm{C}(N=25)$. The third-grade students were divided in the same way; the control group $(N=25)$ and the experimental groups $A$ $(N=25), \mathrm{B}(N=25)$, and C $(N=25)$. The research was conducted in 2009/2010.

The research included 15 classes formed into eight groups (four first grade, four third grade). Some classes were completely included in our research, some only partially. The teachers selected the students that participated in our research in those classes that were not included completely in our 
research. Due to organizational issues, as well as the complexity of the research, most pupils were in schools with day care included. The participants were guaranteed anonymity and were asked to answer truthfully and without fear.

\subsection{Group A-Observing Works of Art}

Group A consisted of first-grade $(N=25)$ and third-grade $(N=25)$ students. After the initial evaluation of their preference (November 2009) regarding art movements up to 1900 and 20th-century art mixed with imagery of no artistic value, they were presented with 20th-century works of art. Compared to the control group, Group A had additional observation of 20th-century works of art (abstract art -9 paintings, fauvism -9 paintings, cubism -9 paintings, pop art -9 paintings, classical-15 paintings, surrealism-4 paintings)

Education in this group was strictly limited to observing reproductions, the first three being the ones students had already seen in the initial preference testing. Every image was viewed carefully for one minute without any comments from research participants. In November, the pupils were shown three works of art, and in the months that followed (up to June 2010) 45 images in all, belonging to 20th-century art movements. In the months in which six reproductions were shown, the pupils observed them approximately every two weeks. After observing the 20th-century works of art, there was an evaluation of preferences at the end of the school year, the same as in other groups.

\subsection{Group B-Educational Use of Puppets}

Group B consisted of first-grade $(N=25)$ and third-grade $(N=25)$ students. They observed the same works of art, but a puppet was used as an educational aid. It was used to explain the characteristics of the art movements of the 20th century and to focus the students' attention on observing the images, the language of visual arts, and the basic characteristics of the art movements, while aiming to clarify the works of art. The exposure procedure was the same as in Group A: in November they were shown three works of art, and in the months that followed (up to June 2010) 45 images in all, belonging to 20th-century art movements. In the months in which six reproductions were shown, the students observed them approximately every two weeks. When meeting the students, conversation about each image lasted 7-10 min in first grade and 10-15 min in third grade.

The reproductions were shown (PowerPoint) on a large screen, and the communication was frontal with the puppet as an aid. The whole group actively participated in observing and commenting on the reproductions. The puppets used were the Rudolf the Reindeer hand puppet (in first grade) and the Janja the Sheep puppet (in third grade).

The puppets were used as communication devices, a medium to motivate the students to be spontaneous and learn about art, all while making it clear that there were no wrong answers and that their observations are all equally valid.

The students were encouraged to be active, participate without fear, and compare thoughts. The puppets were both givers and receivers of information. The students were introduced to the observation method of giving life to paintings and art, which would be practically non-existent if there were no people who observed them.

The examiner encouraged the students, using the puppet, to do the following: 1 . Observe works of art (Look at this painting! Who painted it? Who are the painters? Do you know any painters?) 2. Describe works of art (What is in this painting? Describe what you see and recognize in this painting. Do you see shapes like these in the world around you? Where do you see shapes like these?) 3. Analyze works of art (First grade-Name the colors, primary and secondary. What shapes are shown? Do you see any shapes and colors repeating themselves? Do you see dark and light colors? Third grade-Name the colors, primary and secondary. What shapes are shown? Do you see any patterns of colors and shapes? Do you see dark and light colors? Do you see complementary colors? Do you see the chromatic-achromatic contrast? Do you see warm and cold contrasting colors? Do you recognize any dark-light contrast? Do you see a rhythm and ratio of differently sized shapes?) 4 . 
Interpret works of art (Why do you think the painter painted this? Imagine entering this painting, being inside it. What does this work of art make you feel? What does it remind you of?) The students were introduced to the characteristics of individual art movements through a puppet. 5. Evaluate works of art (After you have found out something about this work of art, how do you feel about it at the moment? What does this work of art mean to you? Can you connect it to something in your life? Who would you give it to as a present?). The education of the students in the experimental groups lasted $15 \mathrm{~h}$ (15 weeks of education).

\subsection{Group C-Creative Artistic Expression/Artwork}

Group $C$, like groups A and B, consisted of first-grade $(N=25)$ and third-grade $(N=25)$ students. The students in group $C$ expressed themselves in shaping art forms according to the 20th-century art movements which Group A observed and Group B discussed using puppets. At the beginning of every educational class, students observed the same works of art that they had seen before. When they were expressing themselves artistically, they used different artistic elements.

When they were introduced to cubism, the students were given the information about the cubist painters wanting to paint unusually, because they did not care about the actual look of an object, instead they wanted to view it playfully in different ways. They melted different sides into a single image. They also wanted to change the qualities of objects observed, simplifying them to basic geometrical shapes (analytical cubism).

Before creative work, the pupils observed different objects from different viewpoints to understand the principles of cubism. The first- and third-grade pupils tried to form their own cubist paintings through different creative motivational games. First- and third-grade pupils tried to create their own cubist paintings through different creative motivational games. In first and third grades, they tried to make a portrait and still life; in the third grade they also painted a cubist landscape.

The pupils were informed that surrealist paintings looked like they were showing wonderful and funny dreams of the artists. Surrealists tried to connect objects and people in new and unexpected ways, ones that do not exist in real life. They were also told that surrealists had a rich imagination, using their art as a way of expressing fears, secrets, dreams, unusual and weird thoughts; their work may seem confusing and frightening because it does not exist in real life. Pupils were encouraged to try to express the untold and unreal. Through creative games, they used motifs of a surrealist portrait and an unusual dream of a clock (first grade), as well as a surrealist self-portrait and an unusual animal (third grade). In both grades, we modified the surrealist cadavre exquis method to make the students finish a drawing started by a small fragment glued to a piece of paper. This resulted in unusual imagery.

In pop art, we explained that the artists depicted only often-seen objects from everyday life. They wanted to show what the contemporary human was surrounded with: comics, ads, stickers on food packaging and bottles, mass-produced objects for everyday use viewed as works of art. The pupils also learned that pop art included famous models, stars, and the latest consumer goods. After learning this, the pupils expressed themselves motivated by pop-art-inspired creative games. In first and third grade, the pupils expressed themselves through motifs of a flag and a popular singer, Severina Vučković. The first-grade pupils also made portraits of Blanka Vlašić, Olympic gold medalist, and the third-grade pupils used consumer goods as motifs.

Fauvism did not require any special explanations. The pupils learned that fauvist painters used clear, strong colors to make the paintings wild and powerful. They often used strong contrast, especially of complementary colors. Purity of colors used made objects, shapes, and landscapes look unusual and slightly skewed. The pupils expressed themselves through portraits and landscapes using strong contrasts of color. The first-grade pupils made self-portraits with an umbrella, the third-grade pupils painted a still life.

To clarify abstract art, we presented the fact that there is no motif or way to decode what the image is showing because the painters were not interested in the real appearance of objects. The pupils 
learned that the painters tried to express the beauty of rhythm and contrast of lines, colors, and shapes that have a language of their own. The pupils were then encouraged to create abstract art. In both the first and second grade, they shaped different abstract compositions. Through creative artistic expression, visual games of recomposing and redefining, using lines, colors, and shapes, mostly with collage, markers, and poster paint, the pupils achieved some interesting visuals.

\subsection{Instruments}

\subsubsection{Abstract Art}

1. Wassily Kandinsky. Red Oval. 1920, oil on canvas.

2. Piet Mondrian. Composition in Color A/Compositie in kleur A. 1917, oil on canvas.

3. Piet Mondrian, Composition with Red, Blue, Black, Yellow, and Gray. 1921, oil on canvas. 4. Franz Kline, Le Gros. 1961, oil on canvas.

4. Robert Motherwell, The Little Spanish Prison, 1941-44, oil on canvas.

5. Jackson Pollock, Untitled, 1951, black and sepia ink on mulberry paper.

6. Jackson Pollock, Untitled (Green Silver), ca. 1949, enamel and aluminum paint on paper, mounted on canvas.

7. Robert Motherwell, Elegy to the Spanish Republic, 70, 1961, oil on canvas.

8. Franz Kline, Black Reflections, 1959, oil and pasted paper on paper, mounted on Masonite.

\subsubsection{Surrealism}

1. Salvador Dalí. The Rotting Donkey. 1928, oil, sand and gravel collage panel.

2. Salvador Dalí. Man of Sickly Complexion Listening to the Sound of the Sea or The Two Balconies. 1929, oil on wood panel.

3. Max Ernst. Birds; also: Birds, Fish-Snake and Scarecrow. c. 1921, oil on canvas.

4. Max Ernst. Ubu Imperator. 1923, oil on canvas.

5. René Magritte. La Durée poignardée. 1938, oil on canvas.

6. René Magritte. Golconda. 1953, oil on canvas.

7. Salvador Dalí, The Persistence of Memory. 1931, oil on canvas.

8. René Magritte. The Pleasure Principle (Portrait of Edward James). 1937, oil on canvas.

9. Max Ernst. L'Ange du foyer ou Le Triomphe du surréalisme. 1937, oil on canvas.

\subsubsection{Fauvism}

1. Henri Matisse. Madame Matisse, "The Green Line". 1905, oil on canvas.

2. Henri Matisse. Dishes and Fruit on a Red and Black Carpet. 1906, oil on canvas.

3. Henri Matisse. The Algerian Woman. 1909, oil on canvas.

4. Maurice de Vlaminck. Autumn Landscape. 1905, oil on canvas.

5. André Derain. Fishing Boats, Collioure. 1905, oil on canvas.

6. André Derain. London Bridge. 1906, oil on canvas.

7. Maurice de Vlaminck. André Derain. 1906, oil on cardboard.

8. Maurice de Vlaminck. The River Seine at Chatou. 1906, oil on canvas.

9. Henri Matisse. The Young Sailor. 1906, oil on canvas.

\subsubsection{Cubism}

1. Juan Gris. Breakfast. 1914. Gouache, oil, and crayon on cut-and-pasted printed paper on canvas with oil and crayon

2. Juan Gris. Violin and Playing Cards. 1913, oil on canvas. 
3. Georges Braque. Still Life with Glass and Letters. 1914, cut-and-pasted printed paper, charcoal, pastel, and pencil on paper.

4. Georges Braque. Guitar. (Summer 1913) cut-and-pasted printed and painted paper, charcoal, pencil, and gouache on gessoes canvas.

5. Georges Braque. Still Life on a Mantelpiece. 1920, gesso, gouache, watercolor, and graphite pencil on paper, mounted on board,

6. Juan Gris. Still Life with Flowers. 1912, oil on canvas,

7. Juan Gris. Mandolin and Grapes. 1922, Gouache and pencil on paper.

8. Juan Gris. Bottle of Rum and Newspaper. 1914.

9. Pablo Picasso, Mandolin and Guitar. 1924, oil with sand on canvas.

\subsubsection{Pop Art}

1. Andy Warhol. Untitled from Marilyn Monroe. One from a portfolio of ten screen prints, composition and sheet.

2. Roy Lichtenstein. Reverie from 11 Pop Artists, volume II. 1965 (published 1966), one from a portfolio of eleven screen prints by various artists, Composition: 27.

3. Roy Lichtenstein. Turkey Shopping Bag. 1964, screen print on shopping bag with handles, Composition: 7.

4. Andy Warhol. À la recherché du shoe perdu. 1955, illustrated book with eighteen photo lithographs with watercolor additions.

5. Jasper Johns. Three Flags. 1958, encaustic on canvas.

6. Andy Warhol. Jackie. 1963, silkscreen ink on polymer paint on canvas.

7. Andy Warhol. Vegetarian Vegetable from Campbell's Soup II. 1969, screen print.

8. Roy Lichtenstein. Drowning Girl. 1963, oil and synthetic polymer paint on canvas.

9. Jasper Johns. Flags. 1968, lithograph.

2.4.6. Paintings before the 20th Century

1. Jusepe de Ribera. The Holy Family with Saints Anne and Catherine of Alexandria. 1648, oil on canvas, $209.6 \times 154.3 \mathrm{~cm}$.

2. Pierre Auguste Renoir. Woman with Parrot (La Femme à la perruche). 1871, oil on canvas, $92.1 \times$ $65.1 \mathrm{~cm}$.

3. Claude Monet. Garden at Sainte-Adresse. 1867, oil on canvas

4. Pieter Bruegel the Elder. The Harvesters. 1565, oil on wood.

5. Édouard Manet. Boating. 1874, oil on canvas.

6. Anthony van Dyck. Self-Portrait. 1620-21, oil on canvas.

7. Canaletto. Piazza San Marco. 1720, oil on canvas.

8. Eugène Delacroix. Ovid among the Scythians. 1862, oil on paper laid down on wood.

9. Paul Cézanne. Mont Sainte-Victoire and the Viaduct of the Arc River Valley, 1882-85, oil on canvas.

10. Rembrandt (Rembrandt van Rijn). Herman Doomer. 1640, oil on wood.

11. Edgar Degas. The Dance Class. 1874, oil on canvas.

12. Jean-Auguste-Dominique Ingres. Madame Jacques-Louis Leblanc (née Françoise Poncelle). 1823, oil on canvas.

13. Vlaho Bukovac. Mladi violinist (Armando Meneghello). 1885, oil on canvas.

14. Diego Rodríguez de Silva y Velázquez. Don Gaspar de Guzmán (1587-1645), Count-Duke of Olivares. ca. 1635, oil on canvas.

15. Paul Gauguin. Still Life with Teapot and Fruit. 1896, oil on canvas. Visual works without artistic value were three reproductions from an interior design magazine. 


\section{Results}

In order to determine the impact of different types of education on artistic preferences, we used $\mathrm{R}$ software [40]. Descriptive statistics and some preparation functions for further analysis were done with the psych package for psychological research [41].

To analyze the differences between the two points (beginning and end of the school year) and impact of treatment on pupils' attitudes to seven different art movements, we used cumulative link models (CLMs) for ordinal data (also called ordinal regression models, or proportional odds models) [42]. Cumulative link models are a different approach to analyzing ordinal data with different types of packages in R; we primarily used the ordinal package [43].

The significance of the effects of treatment were also tested with an analysis of deviance (ANODE) approach, which is analogous to the analysis of variance (ANOVA). These models help us to interpret if there is a significant effect of treatment on preference for different art movements. Post hoc tests were conducted with the lsmeans package and Tukey approach to help us identify a significant difference among groups [43]. The least square means are means for groups that are adjusted for means of other factors in the model [44]. The figures (Figures 1 and 2) were done with the ggplot function within the ggplot2 package [45].

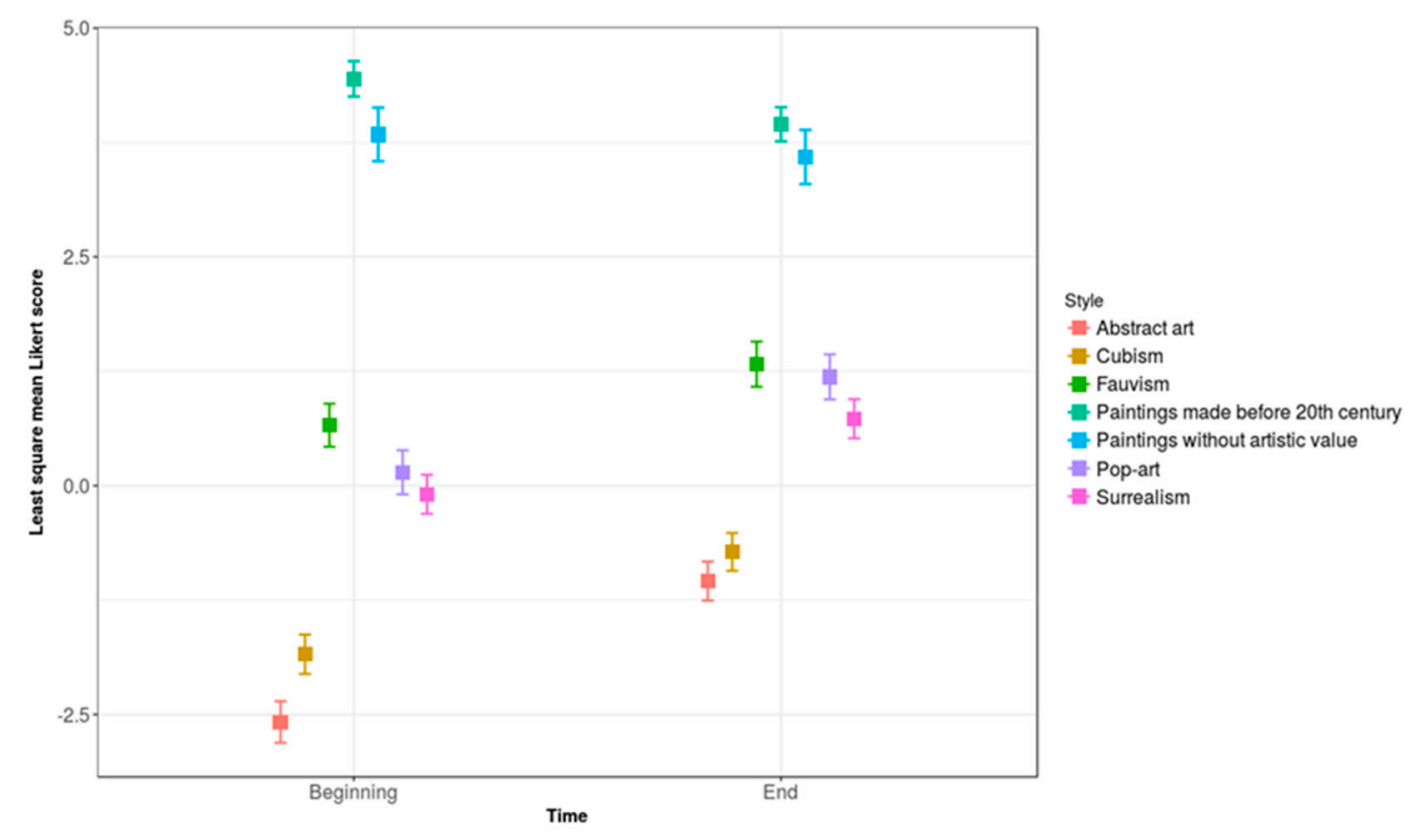

Figure 1. Change of artistic preferences according to time and style.

Figure 1 shows the differences in the least square means of preferences between the beginning and end of the school year among different art movements. There were changes in all styles, with the highest values being at the end of the treatment, except for art made before the 20th century and images without artistic value (Table 1$)$, where we have lower values $(p<0.05)$. 
Table 1. Pairwise comparisons among the least square means according to time and style.

\begin{tabular}{|c|c|c|c|c|c|c|}
\hline Time & Style & Lsmean & $\mathrm{SE}$ & Asymp LCL ${ }^{* *}$ & Asymp UCL ${ }^{* *}$ & Group * \\
\hline Beginning & Abstract art & -2.582 & 0.078 & -2.809 & -2.355 & $\mathrm{a}$ \\
\hline Beginning & Cubism & -1.842 & 0.074 & -2.057 & -1.627 & $b$ \\
\hline End & Abstract art & -1.042 & 0.073 & -1.254 & -0.829 & c \\
\hline End & Cubism & -0.723 & 0.071 & -0.930 & -0.517 & d \\
\hline Beginning & Surrealism & -0.094 & 0.073 & -0.307 & 0.119 & e \\
\hline Beginning & Pop art & 0.146 & 0.083 & -0.095 & 0.387 & e \\
\hline Beginning & Fauvism & 0.660 & 0.081 & 0.425 & 0.896 & $\mathrm{f}$ \\
\hline End & Surrealism & 0.732 & 0.074 & 0.518 & 0.946 & $\mathrm{f}$ \\
\hline End & Pop art & 1.190 & 0.085 & 0.944 & 1.435 & $\mathrm{~g}$ \\
\hline End & Fauvism & 1.328 & 0.085 & 1.081 & 1.574 & $\mathrm{~g}$ \\
\hline End & $\begin{array}{l}\text { Paintings without } \\
\text { artistic value }\end{array}$ & 3.591 & 0.102 & 3.295 & 3.887 & $\mathrm{~h}$ \\
\hline Beginning & $\begin{array}{l}\text { Paintings without } \\
\text { artistic value }\end{array}$ & 3.838 & 0.101 & 3.545 & 4.130 & hi \\
\hline End & $\begin{array}{l}\text { Paintings made before } \\
\text { 20th century }\end{array}$ & 3.949 & 0.064 & 3.762 & 4.136 & $\mathrm{i}$ \\
\hline Beginning & $\begin{array}{l}\text { Paintings made before } \\
\text { 20th century }\end{array}$ & 4.445 & 0.066 & 4.252 & 4.638 & $\mathrm{j}$ \\
\hline
\end{tabular}

${ }^{*}$ Common letter indicates that there were no statistical differences between those groups. ${ }^{* *}$ LCL-Lower Control Limit, UCL-Upper Control Limit.

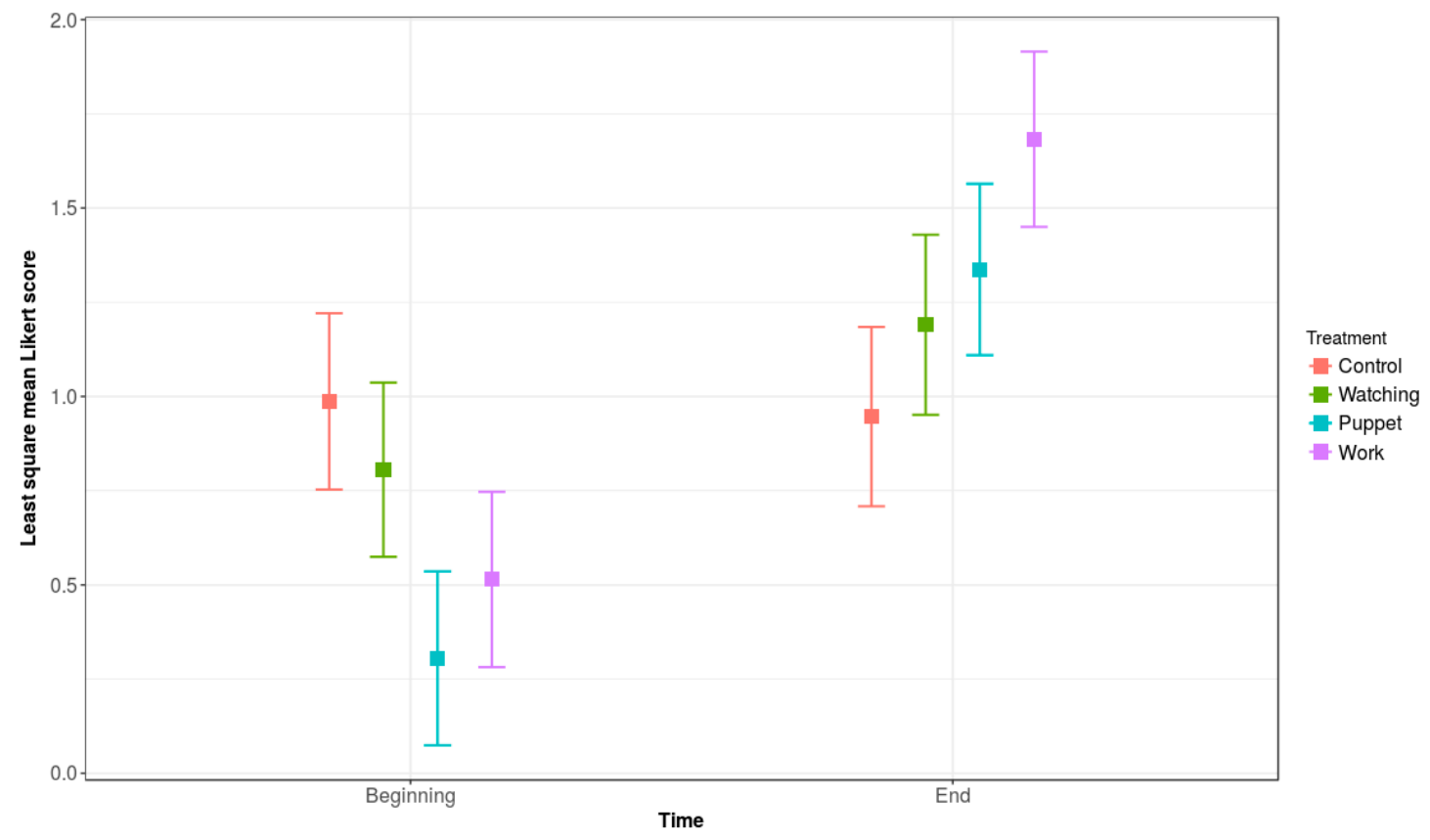

Figure 2. Impact of treatment on artistic preferences.

$$
\mathrm{a}=1 \text {, }
$$

Figure 2 shows the differences in least square means of preferences between the beginning and end of the school year among different treatments.

Table 2 shows the pairwise comparisons according to the results of interaction between time and treatment. In the control group, there were no significant statistical differences between the least square means at the beginning and end of the school year $(p<0.05)$. In all of the other three treatments (watching, puppet, and work), there were statistically significant differences between the beginning and end least square mean values. 
Table 2. Pairwise comparisons among the least square means according to time and treatment.

\begin{tabular}{ccccccc}
\hline Time & Treatment & Lsmean & SE & Asymp LCL & Asymp UCL & Group * \\
\hline Beginning & Puppets & 0.305 & 0.085 & 0.074 & 0.536 & $\mathrm{a}$ \\
Beginning & Work & 0.514 & 0.085 & 0.282 & 0.747 & $\mathrm{ab}$ \\
Beginning & Watching & 0.806 & 0.085 & 0.574 & 1.037 & $\mathrm{bc}$ \\
End & Control & 0.946 & 0.087 & 0.708 & 1.184 & $\mathrm{~cd}$ \\
Beginning & Control & 0.987 & 0.086 & 0.753 & 1.221 & $\mathrm{cde}$ \\
End & Watching & 1.19 & 0.088 & 0.951 & 1.429 & de \\
End & Puppets & 1.337 & 0.083 & 1.11 & 1.564 & ef \\
End & Work & 1.683 & 0.085 & 1.45 & 1.915 & $\mathrm{f}$ \\
\hline
\end{tabular}

* Common letter indicates that there were no statistical differences between those groups.

\section{Discussion}

This research aims to show how different sorts of education influence the preference for works of art belonging to different art movements. Besides that, we have tried to question whether there are differences in that influence considering different art movements. For example, does additional education influence preference more when it comes to the art made before the 20th century or works without any artistic value when compared to abstract art and other 20th-century art movements?

The results indicate the existence of an influence of additional art education on the pupils' preferences, depending on the art movement. The pupils reacted well to different forms of additional education, showing a higher preference for works of art belonging to the periods before the 20th century and works without artistic value. Additional education influenced a change of preference for abstract, cubist, fauvist, surrealist, and pop art. Preference for classical works of art made before the 20th century did not change significantly at the end of school year when compared to the initial preferences.

The research has shown that the current educational curriculum in schools that consists of the observation of works of art is not enough; other sorts of education, such as using puppets and analyzing particular works of art are needed.

The evidence listed leads us to the conclusion that a person's relation to culture is not biologically conditioned, but educationally and culturally conditioned, and this research presents an attitude towards culture as shaped by learning. As Ingarden [46] wrote a long time ago that "what matters in constituting an aesthetic experience is not a spontaneous emotional reaction to the tactile qualities of an object, but a concentrated focus on a qualitative dimension of its existence" [7]. These are the reasons for us to emphasize that formal education is the key factor in pupils' preferences, as is shown by the research data.

Exploring the models of art education regardless of the art movements of the 20th century, we have demonstrated that the lowest positive results in changing pupils' preferences were registered in the group that only observed works of art, while almost equally good results were visible in both the groups learning through a puppet and the ones doing creative work/artwork.

Raskin claimed that experience-even at its simplest level of perception-is never within the "innocent eye" concept [47]; "The way we observe the world, even what we perceive, depends on our horizon of expectation." This horizon is a product of interaction between subjective factors such as needs, preferences, and personal experience on one side, and objective knowledge derived from historical-cultural frames to which an individual belongs on the other [47].

We have also concluded that knowledge of art may have a crucial role in understanding it if the work of art in question is connected to children's experience and feelings, while being incorporated into the activity of creating art. Children working through their own activities have confirmed Piaget's thesis about "the child as the primary builder of their self-understanding" [48]. Taught by the experience of Bruner (especially the part about the importance of teaching and communication in understanding and knowledge) and Vygotsky (especially the zone of proximal development, ZPD), who positions teaching in the center of developing understanding, we may conclude that a child's learning greatly depends 
on learning from and communication with experts. The interactive teacher-student relationship has resulted in a positive change of preferences for lower-grade-school pupils in regard to the 20th-century art movements. The pupils understood how that art was created, under which circumstances, and it enriched their thoughts about the works of art. Teaching, observing, and understanding visual arts is a process requiring time and effort, as well as an interactive environment in which the role of adults in explaining art through different contexts stays a valuable component in understanding.

The research included pupils aged 7-10, with no other groups included, which we see as a limitation. In future research, it would be interesting to include older students, aged 10-18, while introducing some psychological variables such as temper and creativity, and adding more 20th-century art movements.

\section{Conclusions}

We have undoubtedly established that attitudes towards art are formed by learning, which is visible in a positive preference change concerning 20th-century art. We have also confirmed that different sorts of art education, such as observing works of art, introducing works of art with the aid of a puppet, and creative activity/artwork based on the observed art movements, helped pupils understand the art language of particular art movements, which changed their perception of 20th-century art. According to this, art education must change in the direction of the implementation of instruments and tools such as working with puppets and concrete creative work of pupils on 20th-century paintings.

Acquiring knowledge and experience through developing the pupils' creative abilities and nurturing a sense of understanding of the values of art had a positive impact on the pupils' interest in 20th-century art.

New research might explore the application of the described educational models in familiarizing students with art of different styles and from different centuries. Introducing works of art with the aid of a puppet is useful for first-grade students as a means of communicating with works of art.

Author Contributions: Conceptualization, D.K.; methodology, G.K.; validation, G.K.; investigation, D.K.; resources, D.K., M.B.; data curation, G.K.; writing—original draft preparation, D.K.; writing—review and editing, M.B.; supervision, M.B.; project administration, M.B. All authors have read and agreed to the published version of the manuscript.

Funding: This research received no external funding.

Conflicts of Interest: The authors declare no conflict of interest.

\section{References}

1. Anderson, T.; Milbrandt, M. Art for Life: Authentic Instruction in Art; McGraw-Hill: New York, NY, USA, 2004.

2. Eisner, E. The Arts and the Creation of Mind; Yale University Press: New Haven, CT, USA, 2002.

3. Kuščević, D. Mogućnosti povezivanja nastave likovne kulture s drugim nastavnim predmetima u nižim razredima osnovne škole. In Djeca i Mladež u Svijetu Umjetnosti; Ivon, H., Ed.; Filozofski fakultet, Centar za interdisciplinarne studije Studia Mediterranea, Hrvatsko pedagoško-književni zbor. Ogranak Split: Split, Croatia, 2009; pp. 107-120.

4. New, R.S. Children's art as symbolic language: Action, representation, and transformation. Vis. Arts Res. 2007, 33, 49-62.

5. Wilson, B.; Thompson, C.M. Pedagogy and the visual culture of children and youth. Vis. Arts Res. 2007, 33, $1-5$.

6. Winner, E.; Goldstein, T.; Vincent-Lancrin, S. Art for Art's Sake? The Impact of Arts Education; OECD Publishing: Paris, France, 2013.

7. Spajic, V. Vrednovanje Likovnog Djela Pristup Pedagogiji Umjetnosti; Školske novine: Zagreb, Croatia, 1979.

8. Husković, F. Umjetničke galerije i likovne sposobnosti djeteta. In Djeca i mladež u Svijetu Umjetnosti; Ivon, H., Ed.; Filozofski fakultet, Centar za interdisciplinarne studije Studia Mediterranea, Hrvatsko pedagoško-književni zbor. Ogranak Split: Split, Croatia, 2009; pp. 131-135. 
9. Ash, D.; Wells, G. Dialogic inquiry in classroom and museum. In Learning in Places-The Informal Education Reader; Berkerman, Z., Burbules, N., Silbermann-Keller, D., Eds.; Peter Lang: New York, NY, USA, 2006; pp. 35-54.

10. Cox-Peterson, A.; Marsh, D.; Kisiel, J.; Melber, L. Investigation of guided school tours, student learning, and science reform recommendations at museum of natural history. J. Res. Sci. Teach. 2003, 40, 200-218. [CrossRef]

11. Danko-McGhee, K. Favourite artworks chosen by young children in a museum setting. Int. J. Educ. Art 2006, 2, 223-235. [CrossRef]

12. Lachapelle, R.; Murray, D.; Neim, S. Aesthetic understanding as informed experience: The role of knowledge in our art viewing experiences. J. Aesthet. Educ. 2003, 37, 78-98.

13. Salkind, L.; Salkind, N. Gender and Age Differences in Preference for Works of Art. Stud. Art Educ. 1997, 38, 246-256. [CrossRef]

14. Chamorro-Premuzic, T.; Reimers, S.; Hsu, A.; Ahmetoglu, G. Who art thou? Personality predictors of artistic preferences in large UK sample: The importance of openness. Br. J. Psychol. 2009, 100, 501-516. [CrossRef]

15. Furnham, A.M.; Chamorro-Premuzic, T. Personality, intelligence, and art. Personal. Individ. Differ. 2004, 36, 705-715. [CrossRef]

16. Archbell, K.; Stange, K. Relationship of Personality to Preference for Representational Versus Non-representational Art. In Proceedings of the Ontario, Canada: Nipissing University 24 Annual Convention, Chicago, IL, USA, 24-27 May 2012.

17. Wiersema, D. Not just a matter of taste: Individual differences in aesthetic preferences. United Acad. J. Soc. Sci. Amst. Univ. Amst. 2011, 3, 6-16.

18. Cranston, J.P. The nature and development of aesthetic appreciation in children. Br. Psychol. Soc. Q. Bull. 1952, 3, 21-23.

19. Dietrich, G.I.; Hunnicutt, C. Art Content Preferred by Primary-Grade Children. Elem. Sch. J. 1948, 48, 557-559. [CrossRef]

20. Frechtling, J.A.; Davidson, P.W. The development of the concept of artistic style: A free classification study. Psychon. Sci. 1970, 18, 79-81. [CrossRef]

21. Hardiman, G.W.; Zernich, T. Influence of Style and Subject Matter on the Development of Children s Art Preferences. Stud. Art Educ. 1977, 19, 29-35. [CrossRef]

22. Hildreth, G. Color and Picture Choices of Young Children. J. Genet. Psychol. 1936, 49, 427-435. [CrossRef]

23. Katz, E. Children's Preferences for Traditional and Modern Paintings; Teachers College Press: New York, NY, USA, 1944.

24. Kraguljac, M.; Karlavaris, B. Estetsko Procjenjivanje u Osnovnoj Školi; Umjetnička akademija u Beogradu: Beograd, Serbia, 1970.

25. Lark-Horovitz, B. On art appreciation of children: I Preference for picture subjects in general. J. Educ. Res. 1937, 31, 118-137. [CrossRef]

26. Machotka, P. Aesthetic criteria in childhood: Justifications of preference. Child Dev. 1966, 37, 877-885. [CrossRef]

27. Rump, E.E.; Southgate, V. Variables affecting aesthetic appreciation in relation to age. Br. J. Psychol. 1971, 61, 105-110. [CrossRef]

28. Gardner, H. Children's perceptions of works of art: A developmental portrait. In Psychology and the Arts; O'Hare, D., Ed.; Harvester: Birmingham, UK, 1981; pp. 123-147.

29. Ramsey, I.L. The Influence of Styles, Text Content, Sex, and Grade Level on First, Second, and Third Grade Children's Preferences for Artistic Style; Harrisonburg, V.A., Ed.; James Madison University: Harrisonburg, WV, USA, 1979.

30. Taunton, M. The Influence of Age on Preferences for Subject Matter, Realism, and Spatial Depth in Painting Reproductions. Stud. Art Educ. 1980, 21, 40. [CrossRef]

31. Hardiman, G.W.; Zenrich, T. Discrimination of styles in painting: A developmental study. Stud. Art Educ. 1985, 26, 157-162. [CrossRef]

32. Steinberg, D.; DeLoache, J. Preschool children's sensitivity to artistic style in paintings. Vis. Arts Res. 1986, 12, 1-10.

33. Turner, P. Children's responses to art: Interpretation and criticism. J. Art Des. Educ. 1983, 2, 36-42. [CrossRef] 
34. Duh, M.; Herzog, J.; Ros, Š. Preference for visual motifs in first grades of primary school. Innov. Issues Approaches Soc. Sci. 2013, 6, 92-116. [CrossRef]

35. Duh, M.; Herzog, J.; Huzjak, M. Popularity of Art Motifs among Fourth-Grade Primary School Students in Slovenia and Croatia. New Educ. Rev. 2016, 43, 92-103. [CrossRef]

36. Cole, E. The Effect of a Cognitively Oriented Aesthetic Curriculum on the Aesthetic Judgment and Responses of Four-, Six-, and Eight- Year Olds Enrolled in an Art Museum Program. Ph.D. Thesis, University of Toledo, Toledo, Ohio, 1985.

37. Aylward, K.; Hartley, S.; Field, T.; Greer, J.; Vega-Lahr, N. An art appreciation curriculum for preschool children. Early Child Dev. Care 1993, 96, 35-48. [CrossRef]

38. Savva, A.; Trimis, E. Responses of Young Children to Contemporary Art Exhibits: The Role of Artistic Experiences. Int. J. Educ. Arts 2005, 6, 1-22.

39. Acer, D.; Omeroðlu, E. A Study on the Effect of Aesthetic Education on the Development of Aesthetic Judgment of Six-year-old Children. Early Child. Educ. J. 2008, 35, 335-342. [CrossRef]

40. R. Core Team. R: A language and environment for statistical computing. Vienna, Austria: R Foundation for Statistical Computing. Available online: https://www.R-project.org (accessed on 24 December 2019).

41. Revelle, W. Procedures for Personality and Psychological Research, Northwestern University, Evanston, IL, USA. Available online: https://CRAN.R-project.org/package=psych (accessed on 24 December 2019).

42. Mangiafico, S. Summary and Analysis of Extension Program Evaluation in R; Rutgers Cooperative Extension: New Brunswick, NJ, USA, 2016; p. 738.

43. Christensen, R.H.B. Ordinal-Regression Models for Ordinal Data. R Package Version 2010.12-15. 2011. Available online: http://www.cran.r-project.org/package=ordinal (accessed on 30 December 2019).

44. Lenth, R.V. Least-squares means: The R package lsmeans. J. Stat. Softw. 2016, 69, 1-33. [CrossRef]

45. Wickham, H. Ggplot2: Elegant Graphics for Data Analysis; Springer: Berlin/Heidelberg, Germany, 2009.

46. Ingarden, R. Ontology of Work of Art: Musical Work, Picture, Arch, Film; Ohio Universtity Press: Athens, $\mathrm{OH}$, USA, 1989; p. 358.

47. Wenham, M. Art and Science in Education: The Common Ground. J. Art Des. Educ. 1998, 17, 61-70. [CrossRef]

48. Wood, D. Kako Djeca Misle I uče, Društveni Konteksti Spoznajnog Razvitka; Educa: Zagreb, Croatia, 1995. 